and the Territorial Board of Agriculture. All the possible requirements for successful work have thus been filled, namely the most favorable climate (permitting continuous breeding throughout the year), the most favorable conditions of cultivation, a small number of crops, a restricted and simple fauna, a highly intelligent body of men in control, with plenty of means, and an altogether admirable force of scientifically trained employees. As the French would say, Que vouliez vous encore?

What we shall want later is a complete account of the whole work from Mr. Giffard or Dr. Perkins or Mr. Muir or Mr. Swezey. The work has been most notable and should have its written history available to all.

\title{
FURTHER NOTES ON PROSPALTELLA BERLESEI HOW.
}

\section{By L. O. Howard}

The little Aphelinine parasite known as Prospaltella berlesei has become a creature of much international and practical importance, and its name in various combinations, not only as a noun but as a verb as well, has made its entrance into the Italian and Spanish languages, and bids ultimately in these same combinations to enter the English language.

Originally found by Berlese in Florence, issuing from lilac twigs infested by Diaspis pentagona sent from Washington by Marlatt at the writer's request in May, 1906, this parasite was sent back to the writer in Washington, was found to be new, and was described by him as Prospaltella berlesei in an article on the parasites of Diaspis pentagona in Redia, Vol. III, part 2, and in the Entomological News for October, 1906, pp. 292-293. Sendings of parasitized scales from Washington to Florence were continued during 1906, 1907 and 1908.

Berlese's continuous success in rearing and colonizing this parasite on mulberry trees affected by the scale has been reported from time to time, notably in an article in the Journal of Economic ENTOMOLOGY for August, 1912, pp. 325-328, translated by the writer from a French abstract of Berlese's report drawn up by Dr. Caterina Samsonoff.

During the past year Professor Berlese has published in a long article in Redia (X, Parts 1 and 2, May 20,1915, pp. 151-218) a summary account of the warfare in Italy against Diaspis pentagona which at the beginning of the present century threatened the extinction of the silk industry of Italy through the destruction of the mulberry, of the early laws enacted to enforce the mechanical and chemical fight 
against it, of the introduction and spread of the Prospaltella and of its eminent success, until in 1914 a large part of Italy was relieved from the danger, the old laws for its treatment had been canceled, and quarantine on the part of France against Italy had been modified.

Thus the practical introduction and colonization of this Prospaltella in Italy by Berlese has proved to be one of the greatest of the successful efforts of this kind yet carried out.

Attracted by this Italian success, the Prospaltella has recently been introduced from Italy into Switzerland and Spain, and at an earlier date into Uruguay, Argentina, Peru, and Chile-in Uruguay and Argentina from both Italy and the United States, to be used against D. pentagona; and into Peru and Chile from the United States, to be used against other species of Diaspinæ. A certain amount of success has been achieved in the Argentine Republic and in Uruguay, and in the former country a national Prospaltella commission has been founded, under the Ministry of Agriculture, for the purpose of handling the dissemination of the parasites. It is entitled "Comision Nacional Para Propagar la Prospaltella Berlesei How.," and Señor F. A. Barroclavena is the president.

In both Italy and Uruguay the Italian and Spanish equivalents of the verb to Prospaltellize and the noun Prospaltellization have apparently come into general use.

Berlese and Marlatt are probably correct in their belief that Diaspis pentagona is an indigene of tropical oriental countries. Marlatt writes concerning this species: [It] "is common to all eastern Asia, including Japan and the East Indies, and undoubtedly, from its wide distribution and local occurrence in most out-of-the-way districts, is a native of this region and has been spread about in times so remotely past as to be beyond determination. It is probably a tropical species which has worked northward until practically the whole region as far as Peking, China, and the north island of Japan has been covered." 1

Unlike most Aphelinines, Prospaltella berlesei seems to be rather specifically connected with Diaspis pentagona, whereas most of the group may be reared from several Diaspine hosts. It is probable, therefore, that this parasite is also of oriental origin, and in fact the whole genus Prospaltella may very possibly be of tropical oriental origin. Of the twenty-two species which have been described, six have been described from the United States, five from Italy, two from Spain, one from Germany, one from Porto Rico, one from Peru, one from Hawaii, one from India, one from China, one from Java, and three from Australia, but it must be noted that all have been described within the past twenty years, and, as has been frequently pointed out, so great

${ }^{1}$ Bulletin 37, new series, Division of Entomology, p. 78. 
has been the commercial carriage of Coccidæ upon plants imported from one country to another that it is no longer possible to ascertain the original country of the majority of the species, and naturally the same may be said for their parasites. In fact, as I have elsewhere pointed out, ${ }^{1}$ the entire Aphelinine fauna of the United States was radically changed by these accidental importations in the twenty years between 1880 and 1900. Prospaltella berlesei occurs in Japan, as was ascertained by Berlese after its discovery in Italy from twigs sent from Washington. In Washington its host was first discovered about 1894. No effort was made to rear parasites from it until the lilac twigs bearing it were sent to Berlese in 1906 , but the parasite may have come in from almost any part of the world, since plants were being brought to Washington from many points. The manner of the introduction of the scale in Washington is unknown, and there are no data for even a respectable theory. The same must be said of the parasite.

Berlese assumes that: "This species was imported to Washington by Marlatt without his knowledge with material gathered in the extreme east"' (free translation). This assumption is purely theoretical, and, as a matter of fact, is groundless. I myself examined all the parasites reared from the Coccid material sent in by Marlatt, including that reared from Diaspis pentagona shipped as food for Chilocorus similis, and, as Marlatt has pointed out (loc. cit.), the only species reared from this scale were Aphelinus fuscipennis How. and Aspidiotiphagus citrinus (Craw.), the latter being the most numerous. There is no chance that the Prospaltella was unknowingly imported by Marlatt.

Professor Berlese is greatly to be congratulated on the successful outcome of his intelligent and perservering and arduous work in this great experiment, and it is a great satisfaction to the United States Department of Agriculture and to American workers generälly that the United States was able to assist somewhat in return for the many courtesies shown to workers in the Department and in the country generally by Berlese and his Italian colleagues.

The joint session then adjourned. The Association of Economic Entomologists were then photographed on the front steps of the Botany and Zoölogy Building. They reconvened in another room and a paper was presented by Mr. J. R. Parker.

${ }^{1}$ Bulletin de la Société entomologique de France, 1911, No. 12, pp. 258-259. 